\title{
«МУЗИЧНО-ЕКРАННА ФОРМА»: ДО ВИЗНАЧЕННЯ ЗМІСТУ ПОНЯТТЯ
}

У статті розглянуто проблему взаємозв'язку змісту та форми в мистецтві. На основі аналізу музичної та екранної форм авторка пропонуе до вжитку дефініцію «музично-екранна форма», що об'єднує собою екранні твори, в яких музика є формотворчим фактором.

Ключові слова: екранні мистецтва, музична форма, музично-екранна форма, функція музики на екрані, мюзикл.

В статье рассмотрена проблема взаимосвязи содержания и формы в искусстве. На основе анализа музыкальной и экранной форм автор предлагает к использованию дефиницию «музыкально-экранная форма», которая объединит собой экранные произведения, где музыка является формотворческим фактором.

Ключевые слова: экранные искусства, музыкальная форма, музыкально-экранная форма, функция музыки на экране, мюзикл.

The article examines the problem of correlation between content and form in art. Based on the analysis of musical and screen forms, author suggests the definition to use called «musical-screen forms», which combines all the screen works, in which music is a forming factor.

Key words: screen arts, musical form, musical-screen form, the function of the music in the screen, musical.

Культура завжди була й буде віддзеркаленням соціальних процесів. Доступність технологій та засобів комунікації (i, відповідно, безкоштовних «ринків збуту» культурного продукту), передбачена Даніелом Беллом ще в 70-х роках XX ст., зробила мистецтво загальнодоступним для усіх верств населення. Цю очевидну сьогодні десакралізацію зазначив ще в 1936 році Вальтер Беньямін: «Дозволяючи репродукції наближатись до людини, яка іiї сприймає, де б не була, вона актуалізує предмет, що репродукується. Обидва ці процеси викликають глибоке потрясіння традиційних цінностей. Вони перебувають у найтіснішому зв'язку з масовими рухами наших днів. Їх найбільш могутнім представником $\epsilon$ кіно» $[2,22]$. Як бачимо, в десакралізації Беньямін вбачає необхідні позитивні зрушення на шляху до неминучої трансформації мистецтва.

Вільне від картезіанських канонів обов'язкових методів наукового вчення, масове мистецтво розвивається за допомогою нестандартних поглядів творців-непрофесіоналів, «не обтяжених» професійною освітою в галузі. Таким чином збагачується і палітра класичного мистецтва, наповнюючись несподіваними поєднаннями форм, жанрів та стилів, а іноді й продукуючи геть нові.

Сьогодні при вивченні новітніх аудіовізуальних жанрів, в яких музика $є$ провідним, формотворчим чинником, не виявлено жодної дефініції, яка б згруповувала їх в одну когорту. Так, фільм-мюзикл та рок-оперу можна віднести до поняття «музичний фільм». А як же бути з музичним серіалом, блогом, відеоальбомом, кліпом, які також представляють інтерес для науковця? Адже очевидно, що в них простежується ряд спільних ознак, що дає змогу вивести конкретне визначення. Ми пропонуємо термін «музично-екранна форма».

Відсутність точної дефініції робить ці нові форми «невидимими» для наукового дослідження, що обмежує їх розвиток та реалізацію. За словами мистецтвознавця Г. Гачева, перший крок нашої свідомості, коли вона зіштовхується з новим, полягає у визначенні його порядку, жанру, структури, форми та співвідношенні з уже наявними рубриками нашої свідомості - «на що це схоже» 
$[4,9]$. Від гатунку визначення такого першочергового питання залежить якість подальшого проникнення на інші рівні сутності нового явища. Конкретна і знайома форма дає змогу пришвидшити сприйняття нових явищ, саме тому дефініція «музично-екранна форма» розширює кордони для вивчення аудіовізуальних продуктів, де музика виступає формотворчим компонентом та створює поле для вивчення ще не досліджених жанрів, які урізноманітнюють культурну палітру.

Так, сучасна література, присвячена проблемі, окреслюється спеціалізованою музикознавчою (В. Бобровський, Н. Холопова, Б. Асаф'ев) та літературою $з$ теорії кіно (О. Мусієнко, І. Зубавіна). Дослідження ж аудіовізуальних форм, в яких музика відіграє найголовнішу роль, обмежуються переважно дослідженням фільмів-мюзиклів (наприклад, 3. Лісса, М.Боброва, С. Манько). Проте розвідки цих науковців торкаються переважно конкретного різновиду аудіовізуального продукту, його змісту, семантики, тоді як чіткої дефініції форми об'єкта дослідження в працях не виявлено. Значну роль у нашому дослідженні відіграють наукові розвідки Тетяни Шак, яка приділяє велику увагу проблематиці форми музичної та екранної, знаходячи цікаві точки перетину обох понять, а також монографія «Мистецько-видовищні форми сучасної культури» К. Станіславської, де авторка піднімає питання «спрощення та узагальнення термінологічної диференціації» жанрів музично-екранних форм, справедливо зауважуючи, що сьогодні «спостерігаються суттєві розходження у тлумаченні названих жанрів» $[8,90]$.

Поняття змісту та форми в мистецтві тісно взаємопов'язані. Проблематику питання досліджували найвидатніші уми філософії та естетики: Платон, Аристотель, Бекон, Кант, Гегель - це далеко не повний перелік імен тих, кому ми завдячуємо сьогоднішнім розумінням цих дефініцій. Форма покликана передавати духовний посил твору, його основну ідею, відображену за допомогою образів - отже форма є провідником змісту до аудитоpiï. Якщо зміст — це сюжетно-ідейна проблематика твору, то форма - це сама структура його організації. Тобто зміст - це швидше чуттєво-знакове відображення задуму, тоді як форма - логічна послідовність елементів структури твору. Існуючи в тісній залежності одне від одного, але перебуваючи в своєрідному протиставленні, форма і зміст утворюють своєрідну дихотомію, що виражає суть природи мистецтва. Підтвердження тези знаходимо в Гегеля, який виніс проблему співіснування форми і змісту на новий, загальнофілософський рівень: «обставина, що форма визначає себе як зміст таким чином, $\epsilon<\ldots>$ необхідним розвитком того, що відноситься до форми» [5].

Справді, будь-яку ідею твору ми сприймаємо через його форму, що акумулює художній посил автора та структурує його за логікою сприйняття. Можна зробити висновок, що форма — це зовнішній вигляд задуму, змісту твору.

Якщо ж розглядати необхідність введення поняття «музично-екранна форма» з філософської точки зору, можна спертись на думку мистецтвознавця Я. Голосовкера. Сама можливість культурного акту, зазначає він, стимулюється усвідомленням людиною сталості, навіть при найбільш новаторських іiі амбіціях. Якби революціонер не вірив у здійснення свого новаторського ідеалу, він не був би революціонером. Існування такого ідеалу і $є$ тим постійним, сталим, що стимулює його до культурного акту. «Вся аксіологія (філософія цінностей) грунтується на наявності абсолютного критерію <...> Звідси нормативна етика та естетика, канони та парадигми (зразки). Але сам творчий акт та ціль, саме творіння культури (продукт) завжди потребують новаторства, подолання старого, чогось іншого, а не вже відомого, тобто потребують різноманітності та змін. Це і є мінливість-в-сталості», - робить висновок Я. Голосовкер. $[6,27]$, заручаючись підтримкою діалектики.

Отже, в процитованій «Логіці міфу» Яків Голосовкер наголошує власно сформульованим основним законом культури (мінливості-в-сталості) на потрібності новизни; відповідно, науковець повинен досліджувати ці новостворені продукти (термін, використаний самим Я. Голосовкером), згуртовувати їх за особливими характеристиками, пропонувати нову термінологію, яка б змогла умістити їх у зручній дефініції. «Саме прагнення до визначення взагалі є тенденцією до закріплення чогось у певній сталості розуміння» $[6,30]$, - зазначає мистецтвознавець. Так, введенням даного визначення ми намагаємось науково закріпити розмаїття музично-екранних форм, уже широко побутуючих у мистецтві. «Докір в консерватизмі тільки тоді правомірний, коли, <..> відстоюючи сталість, ми забуваємо про основний закон культури - “мінливість-в-сталості"» [6, 31],- підтверджує нашу ініціативу мистецтвознавець.

Оскільки в представленій дефініції саме музика є формотворчим чинником, ключовою складовою виражальної системи окреслених нами екранних форм, то, звернувшись до пояснення 
кожної складової визначення, ми почнемо з музичної форми.

Як і форма в глобальному сенсі, котра покликана передавати основну думку твору за допомогою впізнаваних образів, музична форма - це $\epsilon$ втілення задуму композитора за допомогою звуків, ритму, гармонії, ліричного тексту. Також під музичною формою прийнято розуміти особливі чергування музичних фрагментів (частини, фрази). Поєднання таких фрагментів утворюють різноманітні форми - двочастинну, тричастинну, сонатну, рондо тощо.

Проте, на відміну від звичного трактування форми у філософії (наприклад, за Гегелем), що декларує нерозривність ії поняття від змісту, музична форма проявляє ознаки самодостатності. Вона існує незалежно від інших понять, а зміст ніяк не протиставляється формі композиції. Вона швидше включає в себе, акумулює засоби музичної виразності. Наприклад, для того, щоб якнайточніше реалізувати авторський задум - ідею, зміст твору,композитор користується так званою системою музичних образів: аудіальне втілення глобальної концепції автора виражається в музичних темах, які характеризують персонажа (або одну з його ключових рис), його почуття, події. Наприклад, у поп-опері Е. Ллойд-Веббера «Евіта» музична тема кохання Еви та Перона втілена в чуттєвій румбі, амбіції ж героїні передані дещо жорстким мотивом з роковими інтонаціями, що прямо каже глядачу: героїня не погребує нічим перед втіленням своєї мрії. Ці ключові лейттеми змінюються, трансформуються впродовж поп-опери, без слів передаючи аудиторії настрої та прагнення героїв. Як бачимо, зміст твору, задум автора інтонаційно виражається в музичних темах, що є елементами структури музичного твору, його форми. Вони не протиставляються цілісній формі, проте, прозвучавши одного разу, наступного можуть «виринати» 3 зовсім іншими інтонаціями та ритмами, вони «відокремлюються», запам'ятовуються, живуть навіть поза твором: до прикладу, тема Евіти-«королеви» «Don't cry for me Argentina» часто виконується поза постановкою, проте завжди містить у собі зміст, закладений у ній композитором.

Саме музична форма найбільш схильна до трансформації, і найбільше це помітно «в галузі» популярної музики: композитор відштовхується від наскрізної або куплетної форми, змішуючи елементи за допомогою музичної драматургії (як результат, отримуємо змішані форми), а іноді й видозмінюючи iï до невпізнанності, даючи таким чином життя новій композиційній фігурі.
Такі форми В. Холопова називає «індивідуальна композиція твору» $[9,7]$.

Співвідношення діалектичної єдності протилежностей, 一 пише В. Бобровський, 一 композиції та музичної драматургії - призводять до історично обгрунтованого процесу розвитку музичних форм. Композиція виступає в даній «боротьбі» як «іманентна сторона музичного формотворення» $[3,75]$, тоді як драматургія втілює адекватну реалізацію прообразів авторського задуму, яку композиційні норми покликані спрямувати до реципієнта. Якщо проаналізувати історію музики, відомі тепер музичні форми - соната, рондо, фуга та ін. - кристалізувалися протягом тривалого часу; залишились в історії знаменний розспів, мотет, лауда. Форми, актуальні тепер, довели свою життєздатність в «результаті “осідання" драматургічних функцій в модусі композиційних» [3, 76]: «Єдність композиції та драматургії в підсумку і створює все незліченне багатство музичних “організмів" конкретних творів»,- підсумовує В. Бобровський $[3,76]$.

Якщо ж проаналізувати перелічені вище музично-екранні форми, від кліпу до фільму-рокопери, то, на нашу думку, в музичній основі їх (хіба окрім фільму-балету, в основі якого виключно інструментальна музика) в переважній більшості $€$ вокальна форма. Таке визначення поняття пропонує В. Холопова: «вокальні форми представляють собою групу саме музичних композицій, структура яких лише почасти регулюється формою поетичного тексту - його строфічною побудовою» $[9,8]$. Звісно, вокаліз, скетові композиції - теж вокальні форми, проте і в музичній драматургії, і в екранних творах вони зустрічаються швидше одноразово, тому дане визначення ми вважаємо актуальним для нашої роботи.

Провідна риса музично-екранної форми полягає в тому, що «музичний компонент» тут є не просто черговим зображальним засобом: завдяки йому відбувається розповідь; завдяки своїй емоційності музика допомагає яскравіше розкрити переживання героя, його ставлення до партнера чи ситуації, внутрішній стан. Вокальне вираження написаного тексту є ключовим засобом автора передачі усієї палітри почуттів (а іноді й подій), що їх переживають герої під час сюжетних поворотів. Так, музика і текст виступають тут рівноправними партнерами: музика — як «емоційна складова», текст - як вербальний спосіб передачі конкретної думки героя. Часто текст «йде назустріч» музиці, що певним чином підтверджує, на нашу думку, її пріоритетність у творі: повторення 
окремих слів або, навпаки, «розчленування» слів на розділені паузами склади - ці прийоми покликані маркувати особливі моменти в вокальному номері, імітувати за допомогою музики та слів афективні стани, наголошувати значимість певного слова.

Вокальне виконання авторського тексту збагачує «екранне» полотно картини ще й кліповістю - як додатковим засобом виразності. Іноді кадри епізоду чергуються буквально в такт музиці: подібна «ритмічність» підсилює «емоційне залучення» глядача, надає картині виразності та справжньої «атракціонності». Монтажно поєднуючись таким чином (оскільки монтаж - ключовий елемент ще й музичної композиції), музика та зображення утворюють єдине самодостатнє ціле: акценти в тексті наголошуються хореографічними па, текст акцентується емоційністю музики, музичний номер розкривається завдяки налагодженій наскрізній драматургії. I тільки екранні мистецтва дають змогу найкраще поєднати всі складові завдяки можливості знімати кілька дублів, обирати потрібні ракурси, використовувати монтаж.

Ліричні ж поетичні жанри, закладені в основу вокальних форм, покликані зафіксувати скороминучий момент емоційного сприйняття події чи явища. Як стверджує Г. Гачев: «Кожний вірш вихоплює абсолютно швидкоплинне, те, що ніколи раніше не відбувалось, таким чином, що воно відразу виявляється як ритуальне колишнє. Всі мотиви лірики «переспівані не раз і не п'ять" i вони завжди в новинку» [4, 169]. Лірика як жанр зумовлює акцентуацію суб'єктивно-індивідуальної позиції автора (ліричного героя). Саме тому вона $є$ піддатливою до всіляких трансформацій форми, незважаючи на різноманітність уже наявних на даний момент. А оскільки музична складова в означених нами аудіовізуальних формах $\epsilon$ формотворчою (як уже згадувалось вище), то логічно, що, будучи уже не синтетичними - синкретичними, ці форми схильні до певних трансформацій на догоду домінантній складовій.

Крім того, музична форма, самодостатня за своєю філософською природою, проте схильна до трансформацій, апріорі є рухливою: за визначенням В. Бобровського, «Музична форма - це функціонально рухливий процес інтонаційного втілення конкретної художньої ідеї» [3, 327]. Інтонувати може лише людина, і саме завдяки здатності до інтонування суспільство всотує з розмаїття форм найпотрібніші. Найгеніальніші зразки музичного мистецтва ніколи не займуть свою нішу в ієрархії, не будучи сприйняті суспільством, тому що лише людина, здатна мислити та розмовляти, може віддати належне музичному твору. Блискучий умовивід робить Б. Асаф'єв, однодумець та «натхненник» уже не раз процитованого В. Бобровського: «Не організоване людською свідомістю акустичне середовище ще не становить музики» $[1,23]$. Тому що без сприйняття, «інтонаційного відбору», запам'ятовування, порівняння 3 уже наявними схожими творами (простежується схожість 3 умовиводом Г. Гачева) i, нарешті, естетичної насолоди аудиторії, успіх композитора був би сумнівним.

Тобто ми знову повертаємось до початкового твердження: культура завжди була і буде віддзеркаленням соціальних процесів. Еволюція музичних форм неможлива без еволюції слуху та смаку слухача. Музична форма, більш самостійна ніж інші форми мистецтва (літературна форма не може жити без змісту, на відміну від музичної теми, що може існувати поза суцільним твором), $є$ на додаток ще й найбільш динамічною, сприятливою до трансформацій, особливо в буремні часи доступності контенту та широкої можливості його створення. Для прикладу важливості впливу форми сприйняття музики на їі розвиток згадаймо про колосальні симфонії Бетховена, неможливі без великої концертної зали.

Звернемось тепер до поняття «екранна форма». О. Мусієнко, визнаний експерт у галузі теорії кіно, пропонує таке визначення екранних мистецтв: «це сфера художньо-суспільної діяльності, позначена різноманітними способами відтворення рухомого зображення через різні засоби його проекції на екран» [7]. Це визначення найбільш доцільне нашій науковій розвідці.

О. С. Мусієнко пропонує класифікацію екранних мистецтв залежно від ринку їх поширення:

- кінематограф;

- телебачення;

- відео;

- відео-арт.

Якщо перші два положення зрозумілі, то поняття «відео» варто уточнити словами авторки: «Відео приходить в сім'ю екранних мистецтв спочатку як носій і передавач інформації, а також як засіб зйомки на магнітну плівку». Проте сама дослідниця зазначає, що «естетичне освоєння світу екранними мистецтвами залежить від подальших технологічних здобутків. Ця перспектива завжди залишається відкритою» [7], що дає нам можливість доповнити дану класифікацію. Оскільки спосіб зйомки на електромагнітну стрічку сьогодні втрачає свою популярність, так само як і передавання інформації на матеріальних носіях, 
для нашого дослідження логічно було б замінити дану категорію на поняття Інтернет-площини: вона сьогодні існує і як передавач інформації, і як площина для виникнення та функціонування піджанрів медіа-мистецтва (net art, digital art, phone art тощо).

Як бачимо, і музична, і екранна форми хоч поняття стало-самостійні, та все ж підвладні трансформації. Однак «симбіоз» обох конфігурацій не настільки однобокий, як ми до того звикли. Так, поширена думка, що найчастіше конкретні музичні форми (на кшталт симфоній-саундтреків до фільмів) «включені» в екранні й функціонують виключно в їхніх межах. Проте науковець Тетяна Шак у своїй статті «Методологія аналізу кіномузики в аспекті музичного формотворення» констатує на прикладі ряду фільмів, що спосіб музичного формотворення притаманний і екранним мистецтвам: «спільність музики та кіно як мистецтв процесуальних сприяє тому, що в істоpiї кінематографа можна знайти приклади виявлення на рівні иілісної композиції медіатексту принципів формотворення типових музичних форм-структур» [10].

Виходячи $з$ прийнятих в класичній музиці форм, Т. Шак пропонує три рівні співвідношення музичної та екранної форм:

- музична форма безпосередньо впливає на монтажний ритм та композицію картини (наприклад, мультфільм виробництва студії Дійсней «Фантазія» (1940));

- музична форма витікає з сюжетно-візуального ряду, тобто принцип формотворення фільму витікає 3 принципу музичного формотворення (сама Тетяна Шак наводить як приклад принцип рондальності у фільмі «Іванове дитинство» (1962) — чергування сну як репризи та буденності);

- рівнозначність виявлення музичної форми в музичному та вербально-сюжетному ряді (тобто «музичний» спосіб формотворення використано і в композиції фільму, і в композиції його музичної складової: наприклад, фільм Л. Гайдая «Пес Барбос...» (1961) і принцип рондо-сонати) [10].

Хоч «музичний» спосіб формотворення екранних мистецтв не є предметом цього дослідження, праця Тетяни Шак та процитованих вище науковців дає нам змогу зробити узагальнення щодо характерних ознак запропонованої нами дефініції. Музика — рівнозначний «учасник» картини поруч із драматургією та зображальним рядом. Відповідно, щоб екранний продукт мав право включати в свою дефініцію префікс «музично-», сукупність «драматургічно виконаних композицій» повинна займати бодай чверть екранного часу: кілька творів, виконаних актором під час фільму, ще не декларує його музикальність. У драматургії музична складова виконує ключову роль поряд 3 розмовними діалогами - виражає емоції, розповідає про події та почуття, логічно та натурально випливає 3 передісторії героя. Музичний матеріал подібних продуктів рідко обмежується класичними творами чи стандартними для конкретного соціуму напрямами: навпаки, кожна епоха привносить в музично-екранну форму своє: джаз 50-х, рок 70-х, диско 80-х - усі ці стилі-форми популярної музики серйозно впливали на якість та популярність окремо взятих зразків та на розвиток самої музично-екранної форми. Тому насичення сучасними ритмами - ще одна характерна ознака запропонованої нами дефініції.

Музика як формотворчий чинник зазвичай асоціюється з саме художнім, тобто ігровим кіно. Притому для узагальнення як ЗМI, так і деякі науковці вживають термін «музичний фільм»«кінотвір, в якому музика виконує найважливіші смислові та композиційні функції, визначає жанрову й стилістичну характеристику картини» [11]. «Музичний фільм» в таких джерелах вживається і як жанр кінематографа (як трилер чи бойовик), i як продукт екранного мистецтва 3 наявністю кількох вокальних номерів. Проте дане визначення не характеризує той рівень пріоритетності, який у синтезі мистецтв надано музиці авторами фільму: фільм-ревю, мюзикл, рок-опера дуже відрізняються понятійно та за своїм складом. Та ж ситуація і $з$ дефініціями «фільм-мюзикл» та «фільм-рок-опера». Важливість введення поняття «музично-екранна форма» наголошується й частим вживанням перелічених вище термінів до вочевидь телевізійних проектів, що не мають ознак ні фільму, ні мюзиклу.

Крім того, серед видів кіно і в анімаційному, і в документальному також $є$ незліченна кількість форм з головуванням музичної складової. I якщо наявність таких творів в анімації питань не викликає, то до документального слід підійти дещо ближче.

Маємо колосальне число творів про музику та музикантів, течії та епохи: «Gimme Danger. Icторія Іггі та The Stooges» (2016) Дж. Джармуша, оскароносний «Еммі» (2015) Азіфа Кападіа, «Місто звука» (2013) Дейва Грола тощо. Проте в визначенні їхньої форми також криється колізія. Наприклад, фільм Ельдара Рязанова «Чотири зустрічі з Володимиром Висоцьким» (1987): в одному i тому ж джерелі називається і документальним 
фільмом, і музично-публіцистичною програмою. А в фільмі «Шагренева кістка» (1992) Ігоря Безрукова - симбіозі псевдодокументальної та ігрової естетики - в кінцевій частині відбувається часткова екранізація опери-антракту (переважно балетними номерами) Юрія Хамона, тож почасти фільм $\epsilon$ ще й фільмом-оперою (фактично - балетом).

Так, усі ці твори містяться під дефініцією «(музичні) фільми про музику/музикантів», проте оскільки музика тут $\epsilon$ не лише чинником, що творить їхню форму, - вона ще й визначає їхню тему, об’єкт дослідження автора, вони потрапляють під визначення «музично-екранна форма», яка буде за даних обставин навіть зручнішою: цим ми запобіжимо колізії у визначенні форми подібних творів та матимемо змогу надалі дослідити їх стильову специфіку.

Наприклад, навіть якщо взяти за основу суто ігровий кінематограф, можемо наштовхнутись на низку очевидних суперечностей. Так, хоч музична першооснова дає нам можливість називати художній твір «фільмом-мюзиклом», ми все одно наражаємось на проблему приблизності, не враховуючи сценічну специфіку першоджерела. К. Станіславська пропонує розмежовувати екранізацію музично-драматичних творів та власне кінопостановки з оригінальним сценарієм: «можна додавати префікси “кінофільм-..." чи “телефільм-...", але в обох випадках ми розуміємо, що мова йде про екранну інтерпретацію конкретного сценічного твору» $[8,239]$, тоді як для оригінальних екранних форм, які не мають сценічного аналога, щоб акцентувати на рівні семантики нерозривність, слід вживати терміни «кіномюзикл» чи «телемюзикл». Наприклад, фільм «Мамма Мia!» (2008) є фільмом-мюзиклом, оскільки його першооснова - лондонська постановка 1999 року, а «Мамма Mia! 2» (2018) — є кіномюзиклом, адже стрічка не має аналога на сцені.

Безперечною музично-екранною формою також можна вважати кліп, і не лише тому, що для нього характерна триєдність музики (вокалу та хореографіï), слова (частіше у вигляді поезії) та драматургії. Створений кінематографічними засобами виразності та покликаний «рекламувати» виконавця, кліп як явище виходить за рамки стандартної тривалості та звичного призначення: він і короткометражний фільм (наприклад, екранізація синглу «Bad» (1987) Майкла Джексона Мартіном Скорсезе, тривалістю близько 18-ти хвилин), і набридлива реклама по ТБ, і складова більш повноформатних музично-екранних форм, напри- клад, відеоальбом, кліповий альманах, музичний серіал, талант-шоу.

Різноманітні вияви «екранної адаптації» мистецьких змагань теж належать до категорії «музично-екранна форма». Звісно, їх представники поширені більше на телебаченні та на просторах Інтернету: талант-шоу, різноманітні варіації «блакитних вогників», музичні блоги - тобто продукти «у формі» концертів, відзнятих спеціально для трансляції на будь-якому виді екрана. Такі проекти часто існують не без допомоги драматургії (згадаймо різноманітні «мелодраматичні ходи» популярних талант-шоу, що часто трансформуються в цілі сюжетні лінії). Текст же тут наявний порівну 3 музичною (вокальною, хореографічною) складовою: ведучі, судді, антрепренери, учасники та запрошені гості - усі вони допомагають завершити драматургічно продуманий образ героя/виконавця.

Очевидний також взаємозв'язок екранної культури та відео-арту: згадаймо культову фігуру поп-арту Енді Воргола, роботи якого зробили значний вклад у розвиток класичного кінематографа. Так, висміюючи стандарти кіно, Енді Воргол тим самим не оминув впливу екранної культури на свою творчість. А оскільки музика як формотворчий чинник логічно витікає 3 наявних екранних форм, вона «додала барв» і до відеомистецтва. Наприклад, корейський музикант та скульптор Нам Джун Пайк, надихнувшись дружбою з видатним композитором Джоном Кейджем, взявся до створення музичного відеомистецтва, поєднуючи перфоманс та музику, відеоінсталяцію та гру на музичних інструментах, подарувавши культурному простору такі праці, як «Video Commune», «Hommage a John Cage», «Opera Sextronique».

Важко віднести до будь-якого іншого жанру, окрім поняття «музично-екранна форма», проект литовського композитора Міндгауза Плечайтіса «Piano Cat». Суть його в тому, що зірка YouTube, кішка Нора, яка набула популярності, «зігравши» на фортепіано, виконує партію 3 литовським оркестром. Оркестр виконує акомпанемент наживо, сама ж «зірка» присутня лише на екрані. В майбутньому Плечайтіс планує створити низку подібних проектів для тварин, оскільки «Piano Cat» уже побив усі рекорди популярності.

Підсумовуючи проаналізовані вище поняття музичної та екранної форм, перелічення основних характерних ознак окресленої нами дефініції та виходячи $з$ опису іiі яскравих прикладів, можна запропонувати попереднє визначення терміна: отже, музично-екранна форма — це аудіовізуаль- 
не втілення змісту екранного твору, в якому музика $€$ провідним компонентом виражальної системи, набуваючи засобами екрана нових естетичних властивостей і слугуючи основним чинником народження синтетичних творів.

Логічно, що повна і остаточна кристалізація звичних для кожної епохи звуковисотних та екранно-зображальних співвідношень нереальна, саме тому «практика», тобто створення нових мистецьких форматів, випереджає теорію, тобто вчення про ці самі формати. I якщо в екранних мистецтвах поняття форми невіддільне від поняття змісту, то музична форма сама по собі являється самодостатньою, легкою для трансформації. Музика та відео настільки близько одне до одного супроводжують наше життя (до прикладу, переважна частина користувачів прослуховує музику за допомогою сервісу YouTube), що за кілька років встигли злитись і трансформуватись у низку нових синкретичних форматів, знайомих та впізнаваних реципієнтами.

Кожен термін в мистецтві $є$ поняттям гнучким, піддатливим до реалій об'єктивного йому сьогодення, адже він і існує для того, щоб обмежити коло явищ, які характеризує, щоб замінити багатослів'я на себе, конкретне поняття. Введення нового терміна допомагає позбавитись плутанини, що панує, до прикладу, в царині музичноекранних форм: і хоч надалі потреба в потрібній зараз дефініції може відпасти, наразі вона необхідна, щоб вийти на новий, сучасний рівень дослідження специфіки важливого сектору екранних мистецтв.

\section{Джерела та література:}

1. Асафьев Б. Музыкальная форма как процесс: книга первая и вторая; издание 2-е. Санкт-Петербург: Изд-во «Музыка», 1971. 376 с.

2. Беньямин В. Произведение искусства в эпоху его технической воспроизводимости: избранные эссе. Москва: Медиум, 1996.

3. Бобровский В. Функциональные основы музыкальной формы: исследование. Москва: Изд-во «Музыка», 1978. $331 \mathrm{c}$.

4. Гачев Г.Д.Содержательность художественных форм. Эпос. Лирика. Театр. Москва: Изд-во Московского ун-та, изд-во «Флинта», 2008. 288 с.

5. Гегель Г. Наука логики. Санкт-Петербург: Наука, 1997. URL: http://scicenter. online/teoriya-poznaniya-ontologiya- scicenter/umozaklyuchenie-analogii-der-schluft-der-11807. $\mathrm{html}$

6. Голосовкер Я.Э.Избранное. Логика мифа. Москва; Санкт-Петербург: Центр гуманитарных инициатив, 2010. $496 \mathrm{c}$.

7. Мусієнко О.С. Екранні мистецтва. Сучасна енциклопедія України, 2009. URL: http://esu. com. ua/search_articles. php?id=18811

8. Станіславська К. І. Мистецько-видовищні форми сучасної культури: монографія; вид. друге, перероб. і доп. Київ: НАКККіМ, 2016. 352 с.: іл.

9. Холопова В.Н. Формы музыкальных произведений: учебное пособие. 2-е изд., испр. Санкт-Петербург: изд-во «Лань», 2001. $496 \mathrm{c}$.

10. Шак Т.Ф. Методология анализа киномузыки в аспекте музыкального формообразования. Художественная кульmура. 2014. Вып. 1 (10). URL: http://artculturestudies. sias. $\mathrm{ru} / 2014-1 /$ yazyki/845. html

11. Шилова И. М. Музыкальный фильм. Кино: энцчиклопедический словарь. URL: https://cinema. academic. ru/3749/\% D $0 \% 9$ C $\%$ D $1 \% 83 \%$ D $0 \%$ B $7 \%$ D $1 \% 8 B \% D 0 \% B A \% D 0 \%$ B $0 \%$ D $0 \%$ BB $\%$ D $1 \% 8 \mathrm{C} \%$ D $0 \%$ BD $\%$ D $1 \% 8 \mathrm{~B} \%$ D $0 \%$ B 9 $\%$ D $1 \% 84 \%$ D $0 \%$ B $8 \%$ D 0 \%BB $\%$ D $1 \% 8 C \%$ D $0 \%$ BC

\section{References}

1. Asafiev, B. (1971). Muzykalnaya forma kak protses: kniga pervaya I vtoraya; izdaniye 2-e. Saint-Petersburg: Muzyka, 376 [in Russian].

2. Benjamin, W. (1996). Proizvedeniye iskusstva v epohu ego tehnicheskoy vosproizvodimosti: izbrannye esse. Moscow, Medium [in Russian].

3. Bobrovskiy, V. (1978). Funktsionalnye osnovy muzikalnoy formy: issledovaniye.-Moscow, Muzuka, 331 [in Russian].

4. Gachev, G. D. (2008). Soderzhatelnost hudozhestvennuh form. Epos. Lirika. Teatr.- Moscow, Izd-vo Moscowskogo universiteta, izdatelstvo «Flinta», 288 [in Russian].

5. Hagel, G. (1997). Nauka logiki. URL: http://scicenter. online/ teoriya-poznaniya-ontologiya-scicenter/umozaklyuchenieanalogii-der-schluft-der-11807. html [in Russian]

6. Golosovker, Ya. E. (2010). Izbrannoe. Logika Mifa. Moscow, Saint-Petersburg, Tsentr gumaniyarnyh initsiativ, 496 [in Russian].

7. Musiyenko, O. S. (2009). Ekranni Mystetstva. Suchasna entsyklopediya Ukrainy. URL: http://esu. com. ua/search_ articles. php?id=18811 [in Ukrainian].

8. Stanislavska, K. I. (2016). Mustetsko-vtdoveshchni formy sychasnoi kultury: monografiya; vydannya druge, pereroblene I dopovnene. Kyiv, NAKKKIM, 352 [in Ukrainian].

9. Holopova, V. N. (2001). Formy muzykalnyh proizvedeniy: uchebnoe posobiye. 2-ye izdaniye, ispravlennoe.- SaintPetersburg, izdatelstvo «Lan», 496 [in Russian].

10. Shak, T. F. (2014). Metodologiya analiza kinomuzyki v aspekte muykalnogo formoobrazovaniya. Hudozhestvennaya kultura. № 1 (10). URL: http://artculturestudies. sias. $\mathrm{ru} / 2014-1 /$ yazyki/845. html

11. Shylova, I. M. Muzykalnyi slovar. Kino: entsiklopedicheskiy slovar. URL: https://cinema. academic. ru/3749/\%D 0\%9C\%

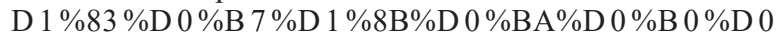
$\%$ BB $\%$ D $1 \% 8 \mathrm{C} \% \mathrm{D} 0 \% \mathrm{BD} \% \mathrm{D} 1 \% 8 \mathrm{~B} \% \mathrm{D} 0 \% \mathrm{~B} 9 \_\mathrm{pD} 1 \% 8$ $4 \% \mathrm{D} 0 \% \mathrm{~B} 8 \% \mathrm{D} 0 \% \mathrm{BB} \% \mathrm{D} 1 \% 8 \mathrm{C} \% \mathrm{D} 0 \% \mathrm{BC}$ 